\title{
Effect of organic loading rate on the recovery of nutrients and energy in a dual- chamber microbial fuel cell
}

Yuanyao Ye ${ }^{\mathrm{a}}$, Huu Hao Ngo ${ }^{\mathrm{a}, \mathrm{c}, *}$, Wenshan Guo ${ }^{\mathrm{a}, \mathrm{c}}$, Soon Woong Chang ${ }^{\mathrm{b}}$, Dinh Duc Nguyen ${ }^{\mathrm{b}}$ Yiwen Liu ${ }^{\mathrm{a}}$, Long Duc Nghiemª, Xinbo Zhang ${ }^{\mathrm{c}}$, Jie Wang ${ }^{\mathrm{d}}$

${ }^{a}$ Centre for Technology in Water and Wastewater, School of Civil and Environmental Engineering, University of Technology Sydney, Sydney, NWS 2007, Australia

${ }^{b}$ Department of Environmental Energy and Engineering, Kyonggi University, 442-760, Republic of Korea

'Joint Research Centre for Protective Infrastructure Technology and Environmental Green Bioprocess, School of Environmental and Municipal Engineering, Tianjin Chengjian

University, Tianjin 300384 and School of Civil and Environmental Engineering, University of Technology Sydney, NSW 2007, Australia

${ }^{\mathrm{d}} \mathrm{sch}$ ool of Environmental and Chemical Engineering, Tianjin Poytechnic University, Tianjin 300387, China

* Correspondence author. Email address: ngohuuhao121@gmail.com; Tel: +61 29514 2745 


\section{Abstract}

This study aimed to assess the impacts of organic loading rate (OLR) (435-870 $\mathrm{mgCOD} / \mathrm{L} \cdot \mathrm{d})$ on nutrients recovery via a double-chamber microbial fuel cell $(\mathrm{MFC})$ for treating domestic wastewater. Electricity generation was also explored at different OLRs, including power density and coulombic efficiency. Experimental results suggested the MFC could successfully treat municipal wastewater with over $90 \%$ of organics being removed at a wider range of OLR from 435 to $725 \mathrm{mgCOD} / \mathrm{L} \cdot \mathrm{d}$. Besides, the maximum power density achieved in the MFC was $253.84 \mathrm{~mW} / \mathrm{m}^{2}$ at the OLR of $435 \mathrm{mgCOD} / \mathrm{L} \cdot \mathrm{d}$. Higher OLR may disrupt the recovery of $\mathrm{PO}_{4}{ }^{3-}-\mathrm{P}$ and $\mathrm{NH}_{4}{ }^{+}-$ $\mathrm{N}$ via the MFC. The same pattern was observed for the coulombic efficiency of the MFC and its highest value was $25.01 \%$ at the OLR of $435 \mathrm{mgCOD} / \mathrm{L} \cdot \mathrm{d}$. It can be concluded that nutrients and electrical power can be simultaneously recovered from municipal wastewater via the dual-chamber MFC.

Keywords: Domestic wastewater; Microbial fuel cell; Nutrients recovery; Energy recovery. 


\section{Introduction}

Over the last decade, chemical fertilizer production on an industrial-scale has become a worldwide issue, and particularly the issue of supplying nitrogen $(\mathrm{N})$ and phosphorus (P). Phosphate-bearing rocks are always exploited for fertilizer production, but they are expected to peter out in terms of supply within the next 30-300 years (Ye et al., 2017). Furthermore, it is difficult to find substitutes of $\mathrm{P}$ in fertilizer production. Thus, the declining deposits of raw $\mathrm{P}$ will result in reducing fertilizer-production capacity. On the other hand, the $\mathrm{N}$ used for producing fertilizer is obtained through the industrial Haber-Bosch process (see Eq. [1]):

$$
\mathrm{N}_{2}+3 \mathrm{H}_{2} \rightarrow 2 \mathrm{NH}_{3}
$$

As shown in Eq. (1), the process needs additional $\mathrm{H}_{2}$ which is derived from fossil sources. High temperature and pressure are the key factors in the ammonia production process, and it is in fact an expensive option requiring large amounts of capital. The energy-intensive process can also cause emissions of carbon oxide $\left(\mathrm{CO}_{2}\right)$ which act as greenhouse gases which are responsible for global warming. Therefore, both the finite natural resource and climate change is forcing many societies to look for sustainable technologies to recover P and N. Besides the benefits of ensuring food security, the recovery of nutrients can also: firstly, mitigate to some extent the problem of eutrophication in aquatic environments; and secondly, reduce the costs associated with nutrient removal in wastewater treatment.

In recent years, wastewater has been considered a renewable resource because it contains many valuable components such as chemical energy, and nutrients such as $\mathrm{PO}_{4}{ }^{3-}-\mathrm{P}$ and $\mathrm{NH}_{4}{ }^{+}-\mathrm{N}$ (Yan et al., 2018). For example, the chemical energy in domestic wastewater is estimated to be at least $13 \mathrm{~kJ} / \mathrm{gCOD}$, which is around 9 times higher than 
the energy used in its treatment (Heidrich et al., 2010). Furthermore, the average energy consumption in conventional wastewater treatment ranges from 0.2 to $0.8 \mathrm{kWh} / \mathrm{m}^{3}$, which is affected by many factors such as the process type, wastewater source, wastewater quantity and composition, removed pollutants, treatment capacities, regional differences including weather and electricity costs, social and economic characteristics (Callegari et al., 2018; Gu et al., 2017; Li et al., 2017; Xu et al., 2018; Yu et al., 2019). It was reported that the consumption of electrical energy for wastewater treatment accounts for $3-5 \%$ of the total electricity demand in the industrialized countries (Curtis, 2010). Hence, optimizing energy consumption and recovering valuable substances, for instance $\mathrm{PO}_{4}{ }^{3-}-\mathrm{P}$ and $\mathrm{NH}_{4}{ }^{+}-\mathrm{N}$ are more important in current wastewater treatment strategies.

Microbial fuel cells (MFCs) constitute a bioelectrochemical system and can sustainably recover electricity and nutrients through the catalysis of electroactive bacteria (Callegari et al., 2018; Ye et al., 2019). The system can directly convert the chemical energy contained in an organic substrate into electrical energy, during which there is no input of combined heat and power unit. In addition, this technology obviously provides a potentially attractive alternative for treating wastewater compared to the conventional aerobic or anaerobic treatment of wastewater. For instance, the MFC has advantages over the aerobic activated sludge technology due to producing less surplus sludge, faster process kinetics and lower energy input (e.g., aeration supply) in the wastewater treatment (Gil et al., 2003). Furthermore, anaerobic degradation rates in the MFC are faster than those in the traditional anaerobic wastewater treatment. For example, Morris et al. (2009) previously found that the anaerobic biodegradation of diesel range organics was significantly enhanced using an MFC (82\% removal 
efficiency) when compared to the anaerobic treatment (31\% removal efficiency).

Moreover, the anaerobic degradation rate for phenol was $11.3 \pm 0.7 \mathrm{mg} / \mathrm{L} \cdot \mathrm{d}$ (Franchi et al., 2018) whereas the MFC could achieve the removal rate of phenol at $128.7 \pm 26.3$ $\mathrm{mg} / \mathrm{L} \cdot \mathrm{d}$ (Luo et al., 2009).

An anode compartment and a cathode compartment consist of the conventional MFC, which are separated by a cation exchange membrane (CEM) (Yan et al,, 2018). The anode compartment is responsible for the microbial degradation of substrate and generation of electron and proton, while the electrical loop is completed in the cathode chamber equipped with electron acceptors (e.g., $\mathrm{O}_{2}$ ) (see Eq. [2]). Apart from this, the transported protons react with electrons and oxygen (i.e., the electron acceptor) to form water molecules at the cathode (see Eq. [3]).

$$
\begin{aligned}
& 2 \mathrm{H}_{2} \mathrm{O}+\mathrm{O}_{2}+4 \mathrm{e}^{-} \rightarrow 4 \mathrm{OH}^{-} \\
& 2 \mathrm{H}^{+}+2 \mathrm{e}^{-}+\mathrm{O}_{2} \rightarrow 2 \mathrm{H}_{2} \mathrm{O}
\end{aligned}
$$

Investigations into the recovery of $\mathrm{PO}_{4}{ }^{3-}-\mathrm{P}$ and $\mathrm{NH}_{4}{ }^{+}-\mathrm{N}$ through MFCs from wastewater have been conducted in recent years and the reactor configurations of an MFC include the following versions: single chamber (or air-cathode), dual-chamber, and multi-chamber with different materials of electrodes and separators (Ichihashi \& Hirooka, 2012; Yan et al., 2018). So far, the recovery of $\mathrm{PO}_{4}{ }^{3-}-\mathrm{P}$ and $\mathrm{NH}_{4}{ }^{+}-\mathrm{N}$ via $\mathrm{MFC}$ has mainly been achieved by the formation of nutrients-based precipitates. For example, an air-cathode MFC was developed by Ichihashi and Hirooka (2012) to recover $\mathrm{PO}_{4}{ }^{3-}-\mathrm{P}$ and $\mathrm{NH}_{4}{ }^{+}-\mathrm{N}$ from swine wastewater, using a rectangular reactor equipped with a cathode coated by $0.5 \mathrm{mg} / \mathrm{cm}^{2}$ of Pt/C catalyst. In this scenario, the researchers successfully recovered nutrients via the formation of struvite. However, the amount of phosphate recovered at the cathode was only $27 \%$. The possible reason for this is that 
the electrolyte was shared by the anolyte $\left(\mathrm{H}^{+}\right.$generation $)$and catholyte $\left(\mathrm{OH}^{-}\right.$ generation), thereby impeding the elevation of catholyte $\mathrm{pH}$ (Zhao et al., 2006). Consequently, the formation of nutrients-based precipitates at the cathode was seriously compromised in the single-chamber MFC.

Other studies also demonstrated the application of multi-chamber MFC for recovering nutrients, which uses a stack of CEMs and anion-exchange membranes (AEMs) (Chen et al., 2015; Chen et al., 2017). In this scenario, the system can highly concentrate the nutrients from wastewater. Chen et al. (2015) reported that the concentrations of $\mathrm{NH}_{4}{ }^{+}$and $\mathrm{PO}_{4}{ }^{3-}$ were 1.5 and 2.2 times higher than the initial concentration, respectively. However, an input of alkaline chemicals such as $\mathrm{NaOH}$ is necessary to offer high $\mathrm{pH}$ for nutrients recovery through chemical precipitation. To date, analyses into applying a MFC to recover nutrients are a few (Ichihashi \& Hirooka, 2012; Marzorati et al., 2018) whereas studies on recovering nutrients via doublechamber MFCs at laboratory scale are rarer still. Nevertheless, the few available studies still present highly important findings for applications of MFCs, such as explaining the advantages of its application (Ye et al., 2019). In a recent study, a new dual-chamber MFC was built and then employed for simultaneously recovering $\mathrm{PO}_{4}{ }^{3-}-\mathrm{P}$ and $\mathrm{NH}_{4}{ }^{+}-\mathrm{N}$ from domestic wastewater (Ye et al., 2019). The precipitates formed in the cathode chamber and the analytical results suggested that the characterization of obtained precipitates was similar to the struvite, which suggests the feasibility of the doublechamber MFC for nutrients recovery.

Generally, the MFC's performance is mainly influenced by four processes, these being catalytic reaction of anaerobic bacteria for the substrate, transport of electrons from microorganisms to the anode electrode, transfer of protons from the anode to 
cathode and the reduction of the electron acceptors in the cathode chamber (Gil et al., 2003; Mardanpour et al., 2017). The organic loading rates (OLRs) are highly relevant to these four processes; for example, Di Lorenzo et al. (2010) found that increasing OLR from 16 to $161 \mathrm{kgCOD} / \mathrm{m}^{3} \cdot \mathrm{d}$ could decrease the coulombic efficiency from $68 \pm 7.2 \%$ to $49 \pm 2.7 \%$ and undermine the maximum current generation. This is because the nonexoelectrogens are more active than the electrochemically active bacteria at higher COD loadings and consequently lower coulombic efficiencies are obtained. In contrast, Aelterman et al. (2008) observed that doubling the OLR resulted in an increase in the current generation at low external resistance $(10.5-25 \Omega)$ or during polarization. This contradiction may be attributed to the differences in the electrode materials, carbon sources and other factors that affect the electricity generation. In the present study, the main objective is to evaluate the effects of OLR on the long-term MFC performance for municipal wastewater treatment. A complete assessment of MFC was conducted, including the generation of power, efficiency in removing COD and especially the efficiency in nutrients recovery.

\section{Materials and methods}

\subsection{Experimental setup}

The double-chamber MFC was constructed using a previously described design (Ye et al., 2019), containing an anode chamber and a cathode chamber in rectangular form. The two chambers were made of plexiglass and placed on opposite sides and separated by a CEM (CMI7000, Membranes International Inc., USA). In the MFC reactor, each compartment had an effective volume of $350 \mathrm{~mL}$. The anode electrode was composed of graphite felt (Sanye Carbon Co. Ltd., Beijing, China) in the cylinder- 
shaped form with a diameter and thickness of $30 \mathrm{~mm}$ and $60 \mathrm{~mm}$, respectively. On the other hand, a carbon-fiber brush served as the cathode electrode, it being $3 \mathrm{~cm}$ in length and $3 \mathrm{~cm}$ in diameter, and coated with a titanium bar. The anode electrode and cathode electrode were connected by a copper wire with a resistance of $1000 \Omega$.

Synthetic domestic wastewater used for culturing the inoculum at the anode was prepared employing a specific amount of glucose, which made the corresponding influent COD concentrations range from 300 to $600 \mathrm{mg} / \mathrm{L}$. Other components in it included $0.0046 \mathrm{~g} \mathrm{KH}_{2} \mathrm{PO}_{4}, 0.02 \mathrm{~g} \mathrm{NH}_{4} \mathrm{Cl}, 0.0054 \mathrm{~g} \mathrm{MgSO}_{4} \cdot 7 \mathrm{H}_{2} \mathrm{O}, 0.0004 \mathrm{~g}$ $\mathrm{CaCl}_{2} \cdot 2 \mathrm{H}_{2} \mathrm{O}, 0.032 \mathrm{~g}$ yeast and $0.61 \mathrm{~mL}$ of trace nutrients per litre of distilled water (DI water). The synthetic solution served as the feed solution and was continuously pumped to the anode compartment at a constant volumetric flow rate of $0.35 \mathrm{~mL} / \mathrm{min}$ through the control of a peristaltic pump (Model 77202-60, Masterflex, Illinois, United States). The $\mathrm{NaHCO}_{3}$ and $\mathrm{H}_{2} \mathrm{SO}_{4}$ solutions were employed to adjust the $\mathrm{pH}$ of the feed solution to $7.0 \pm 0.15$ prior to its addition, which is confirmed by a $\mathrm{pH}$ meter (hi9025, Hanna Instruments, Limena, Italy). It should be noted here that no assessment of the internal $\mathrm{pH}$ control's behavior was conducted in the present study.

\subsection{Inoculum and experimental operation}

The anaerobic sludge was collected from the Cronulla wastewater treatment plant (Greenhills Beach, New South Wales, Australia), and this sludge served as the inoculum at the anode compartment in the double-chamber MFC. To acclimatize the inoculum, the external circuit was opened and the dual-compartment MFC was continuously fed under room temperature $\left(24 \pm 2{ }^{\circ} \mathrm{C}\right)$ for one month before starting the experiment. After that, the MFC could be operated under closed circuit and then used to treat wastewater at different organic loading rates (OLRs) which were achieved by various influent COD 
concentrations with a fixed hydraulic retention time (HRT). The anode chamber was maintained under the anaerobic environment while DI water was exploited as the catholyte with aeration supplied ( $\mathrm{DO}=6 \mathrm{mg} / \mathrm{L})$. A DO meter (OM-51, Horiba, Tokyo, Japan) was used to monitor changes in the DO concentration of the catholyte. The anode effluent directly served as the cathode compartment' influent without any extra adjustment. A diagram of the experimental setup has been provided in another study (Ye et al., 2019). The MFC's performance was investigated at four different periods and each one lasted for 30 days (Table 1).

\subsection{Data analysis}

The aqueous samples from the anode effluent and cathode effluent were analyzed daily, including the concentrations of COD, $\mathrm{PO}_{4}^{3--}-\mathrm{P}$ and $\mathrm{NH}_{4}{ }^{+}-\mathrm{N}$, and $\mathrm{pH}$ values. The samples to determine the influent COD concentration were taken from the anodeinfluent storage bottle while refreshing the feed solution. All the aqueous samples were firstly filtered by a $0.12-\mu \mathrm{m}$ membrane (Tianjin Jinteng Experimental Equipment Co. Ltd., Tianjin, China) and then employed for further measurement. In this scenario, the $\mathrm{COD}, \mathrm{PO}_{4}{ }^{3-}-\mathrm{P}$ and $\mathrm{NH}_{4}{ }^{+}-\mathrm{N}$ contents were determined using Spectroquant ${ }^{\circledR}$ Test Kits (NOVA 60, Merck) by using the standard methods (Federation \& Association, 2005). Furthermore, the voltage generated in the MFC was daily monitored and measured three times at least using a universal digital meter (VC86E, Shenzhen City Station Win

Technology Co. Ltd., Shenzhen, China). When the value remains constant or fluctuates only negligibly then the state condition of MFC is considered to be steady. After each change in the OLR, the reactor was run until a new steady state condition at the new OLR was achieved. 
According to Ohm's law, the current $(I)$ generated by the MFC was given by Eq.

(4).

$$
I=\frac{U}{R}
$$

where $U(\mathrm{mV})$ is the voltage generated by the MFC and measured by the digital meter; $R(\Omega)$ is the external resistor at 1000 .

The power output $(P, \mathrm{~W})$ and power density $\left(P_{A}, \mathrm{~W} / \mathrm{m}^{2}\right)$ are calculated through the following equations:

$$
\begin{gathered}
P=U I \\
P_{A}=\frac{P}{A}
\end{gathered}
$$

where $A\left(\mathrm{~cm}^{2}\right)$ is the surface area of the anode electrode (in the present case on both sides).

The value of coulombic efficiency $\left(C_{E}, \%\right)$ which is linked to the electrons' recovery is given by Eq. (8) (Logan, 2008).

$$
C_{E}=\frac{8 \int_{0}^{t} I d t}{F \Delta \operatorname{CODV}} \times 100 \%
$$

where $t(\mathrm{~d})$ is the running time of MFC reactor; $F(\mathrm{C} / \mathrm{mol})$ is the Faraday's constant at 96485; $V(\mathrm{~mL})$ is the effective volume of the anode chamber in the MFC; and $\triangle C O D$ $(\mathrm{mg} / \mathrm{L})$ is the amount of COD removed in the double-chamber MFC.

\section{Results and discussion}

\subsection{COD removal efficiency}

The double-chamber MFC's efficiency in removing COD was explored in the OLR range from 435 to $870 \mathrm{mgCOD} / \mathrm{L} \cdot \mathrm{d}$, as shown in Fig. 1. According to this figure, it was clearly evident that the COD removal efficiencies were more than $90 \%$ when the OLR increased from 435 to $720 \mathrm{mgCOD} / \mathrm{L} \cdot \mathrm{d}$. However, if OLR was too high (i.e., 870 
$\mathrm{mgCOD} / \mathrm{L} \cdot \mathrm{d})$ this scenario resulted into COD removal efficiency declining to around $70 \%$. A similar result concerning the impact of OLR on the removal of organics in the MFC was reported in another study (Liu et al., 2016). In contrast, Molognoni et al. (2016) believed that the higher removal efficiency of carbon can be obtained in substrate limiting conditions $(\mathrm{OLR}<1000 \mathrm{mgCOD} / \mathrm{L} \cdot \mathrm{d})$. This contradiction may be attributed to different species of anaerobic microorganisms being used in the wastewater treatment. Moreover, Tamilarasan et al. (2017) have reported that methanogenic organisms account for COD removal at higher OLR. Excessive organics provide a niche for methanogens, and where the OLR is higher than the maximum electron transfer rate of the MFC results in methanogenesis (He et al,, 2005). These findings highlighted the importance of OLR for COD removal in the wastewater treatment because optimized OLR can assist anaerobic microorganisms to effectively utilize the substrate. As well, each change in the OLR may cause a reduction in COD removal efficiency, which may be ascribed to acclimation of anaerobic bacteria at the anode chamber under a new OLR.

In the dual-compartment MFC, the COD removal was achieved by the combined effects of electrogenic and non-electrogenic microorganisms at the anode chamber for microbial degradation (Logan, 2008). Furthermore, the formation of a biofilm on the surface of the anode electrode could help CDO removal and the adsorption of organics to the anode surface (Tamilarasan et al., 2017). There are in fact many factors affecting the COD removal via MFC, such as sources of wastewater and inoculum, MFC configurations and electrode properties, which makes it difficult to compare MFC studies on the subject of COD removal. 


\subsection{Electricity generation}

In this section, Fig. 2 below depicts the variations in voltage generation at different OLRs (435 to $870 \mathrm{mgCOD} / \mathrm{L} \cdot \mathrm{d}$ ) while applying the dual-compartment MFC to treat municipal wastewater.

Overall, the voltage generated by the double-chamber MFC fluctuated at each period. This may be attributed to slight changes in the concentration of feed solution and environment such as room temperature. Generally, the voltage generated in the MFC is related to the concentration of carbon source and their utilization efficiency by the anaerobic microorganisms. During the first period the average electricity generation was more than $550 \mathrm{mV}$. A possible reason for this is that the operation mode of the double-chamber MFC was under open circuit for 30 days prior to the experiment, during which the biofilm started to form on the anode electrode's surface and thereby made electricity generation possible. It was reported that the substrate can be exploited by inoculum for electricity generation within $24-72 \mathrm{~h}$ due to the acclimatization of the inoculum (Tamilarasan et al., 2017). The maximum voltage generated in the doublechamber MFC was $598.9 \mathrm{mV}$ at the OLR of $435 \mathrm{mgCOD} / \mathrm{L} \cdot \mathrm{d}$.

Additionally, it could be seen that higher OLR may cause a decline in the amount of electricity being generated in the double-chamber MFC. This may be because low COD concentrations (i.e., OLR) could facilitate electricity production (Hiegemann et al., 2016). Moreover, higher OLR of the anode chamber may lead to a larger risk for membrane fouling, which may detrimentally influence the voltage generation (Elakkiya \& Matheswaran, 2013). This had also been detected in the study by Sobieszuk et al. (2017) and they thought that the history of previous OLRs may also strongly influence the electrochemical behavior of the system (del Campo et al., 2013; Sobieszuk et al., 
2017). Moreover, He et al. (2015) believed that higher OLR may result in the accumulation of volatile fatty acid (VFA), which may not facilitate the generation of electricity in the dual-component MFC. As discussed in section 3.1, the activity of methanogenic microorganisms increased due to higher OLR, which in turn weakened the electricity generation-capacity of the electrogenic bacteria. Juang et al. (2011) thought that the MFC could achieve its maximum value of voltage generated at a certain OLR and the value would decrease if the OLR increased.

Nevertheless, it could also be observed that the growth of OLR from 580 to 870 $\mathrm{mgCOD} / \mathrm{L} \cdot \mathrm{d}$ simply increased the voltage generation from 318.2 to $482.6 \mathrm{mV}$. This is because higher OLRs could evidently offer more substrates (e.g., organic matter) for the electrogenic bacteria, which facilitated the recovery of chemical energy. Some researchers believed there is a relationship between the amount of voltage generated in the MFC and influent COD concentration. For instance, Di Lorenzo et al. (2010) found that a drop in the influent COD concentration of 10 -fold led to an around $31 \%$ - and $53 \%$-reduction of the current generation and power output, respectively. In a biocathode MFC with the tubular membrane, Wang et al. (2014) reported that the correlation between current and inlet COD concentration $(0-3000 \mathrm{mg} / \mathrm{L})$ could be expressed as shown in Eq. (8) with correlation coefficient $\left(R^{2}\right)$ of 0.87 , in which the $y$ $(\mathrm{mA})$ represents the current whereas the $x(\mathrm{mg} / \mathrm{L})$ represents the inlet COD concentration. Similarly, Jia et al. (2016) also proposed the following Eq. (9) to present the correlation between voltage $(y, \mathrm{~V})$ and COD concentration $(500-3000 \mathrm{mg} / \mathrm{L})(x$, $\mathrm{mg} / \mathrm{L})$ with $R^{2}$ of 0.94 .

$$
\begin{aligned}
& y=\frac{0.906 x}{267.609+x} \\
& y=3 \times 10^{-5} x+0.2452
\end{aligned}
$$


However, Fig. 2 shows that COD removal efficiency may not have a direct relationship with electricity generation. Thus stable COD removal efficiency did not always reflect the stabilization of the voltage due to the nature of the microbial conversion pathways (Sobieszuk et al., 2017). Furthermore the removal of COD was realized by the combined effects of all microbial species present in the anode compartment and affected by their concentrations and balance. By contrast, the electrogenic bacteria' activity and concentration is the only factor to determine the electricity generation (Sobieszuk et al., 2017; Yu et al., 2015).

For MFCs working in continuous mode, each MFC has a maximum value of voltage generation for different OLRs and the value varies from different MFC configurations. The maximum value of voltage generation obtained in the present study and the corresponding value of power density for different OLRs are depicted in Fig. 3. It can be seen that the maximum voltage generation was $598.9 \mathrm{mV}$ at the OLR of 435 $\operatorname{mgCOD} / \mathrm{L} \cdot \mathrm{d}$, which was 1.5 times higher than that reported by Rossi et al. (2018) for treating domestic wastewater via an air-cathode MFC. In comparison to the value reported by Wei et al. (2012), the value present in this study was over $200 \%$ higher than their values at different OLRs. This indicated that the electrogenic bacteria cultured in the present study had higher utilization efficiency for the substrate when compared to inoculums reported in other studies (Tamilarasan et al., 2017). However, Wang et al. (2010) who used a double-chamber continuous MFC, achieved a voltage of $706 \pm 21$ $\mathrm{mV}$, which is over $10 \%$ higher than our maximum voltage production. This may be ascribed to the inoculation of algae at the cathode chamber. In this scenario, generating the oxygen through the photosynthesis could sustain cathodic oxygen reduction, which improved the MFC reactor's electrochemical performance (Colombo et al., 2017). 
While increasing the OLR from 435 to $870 \mathrm{mgCOD} / \mathrm{L} \cdot \mathrm{d}$, the power density ranged from 71.66 to $253.84 \mathrm{mV} / \mathrm{m}^{2}$. The low power density achieved in the double-chamber MFC may be attributed to the component of municipal wastewater that served as the feed solution (Yu et al., 2015). Nevertheless, the smaller power density values were often observed in many other studies (Zhou et al., 2013). However, Ichihashi and Hirooka (2012) reported a power density of $2300 \mathrm{~mW} / \mathrm{m}^{2}$ in an air-cathode MFC using a coating of $0.5 \mathrm{mg} / \mathrm{cm}^{2}$ of $\mathrm{Pt} / \mathrm{C}$ catalyst on wet-proofed porous carbon paper as the cathode electrode in the treatment of swine wastewater. Notably, the pretreatment of the cathode with catalyst improved the power density. Besides, using a polyester nonwoven cloth as the separator could avoid any danger of membrane fouling, which facilitated the recovery of electricity. Similarly, Chen et al. (2015) obtained a power density of 224 $\mathrm{mW} / \mathrm{m}^{2}$ through the usage of a multi-chamber MFC, using granular activated carbon as the anode electrode.

On the other hand, the coulombic efficiency fell when OLR increased. This is because the anode surface with high saturation may induce side-populations (methanogens, heterotrophs) to compete with electrogenic bacteria for the substrate (Velvizhi \& Mohan, 2012), therefore weakening the activity of electrogenic microorganisms. At the OLR of $435 \mathrm{mgCOD} / \mathrm{L} \cdot \mathrm{d}$, the maximum coulombic efficiency was around $25 \%$, which was the highest power density reported in the present study. The possible reason for this is that utilizing substrate for methane production was reduced and electroactive bacteria is better in the ascendancy compared to other microbial populations at low OLR (Callegari et al., 2018). Apart from this, the minimum coulombic efficiency was recorded as $2.21 \%$ at the OLR of $870 \mathrm{mgCOD} / \mathrm{L} \cdot \mathrm{d}$. The maximum value of coulombic efficiency obtained in the present study was lower 
than that derived from Ichihashi and Hirooka (2012), mainly due to the component of wastewater source and material of the electrode. However, the present MFC showed higher values of coulombic efficiency compared to that reported in other researches (Chen et al., 2015; Colombo et al., 2017; Marzorati et al., 2018). Besides, the MFC at laboratory-scale was continuously fed for $120 \mathrm{~d}$, longer than many other studies on the MFC applications in the wastewater treatment (Chen et al., 2015; Colombo et al., 2017; Ichihashi \& Hirooka, 2012; Marzorati et al., 2018).

In addition, energy loss is unavoidable in this study and derived from anode overpotential, transport loss, etc. (Puig et al., 2012). The development of electrode material and/or bio-cathode could satisfy an improvement in energy recovery due to reduction in the electrode over-potential (Callegari et al., 2018). As well, the energy losses resulted from membrane ionic transport could be reduced through the application of CEM with lower internal resistance or being less subject to biofouling (Angioni et al., 2016). A more attractive method is to use a membrane-less MFC to curtail the energy losses (Vicari et al., 2018). Nevertheless, the costs and efficiency of such strategies must be taken into account and it should be remembered that the present aim of this dual-chamber MFC is to maximize nutrients recovery rather than electricity recovery.

\subsection{Nutrients recovery}

The effects of OLR on nutrients recovery in the dual-compartment MFC are shown in Fig. 4. According to this figure, the removal of $\mathrm{NH}_{4}{ }^{+}-\mathrm{N}$ and $\mathrm{PO}_{4}{ }^{3-}-\mathrm{P}$ in the anode effluent was enhanced by increasing the OLR. For example, the average efficiency in removing $\mathrm{NH}_{4}{ }^{+}-\mathrm{N}$ and $\mathrm{PO}_{4}{ }^{3-}-\mathrm{P}$ in the anode effluent were $14 \%$ and $12.43 \%$, respectively, at the OLR of $435 \mathrm{mgCOD} / \mathrm{L} \cdot \mathrm{d}$. It should be noted here that the removal 
of $\mathrm{NH}_{4}{ }^{+}-\mathrm{N}$ and $\mathrm{PO}_{4}{ }^{3-}-\mathrm{P}$ in the anode compartment was obtained by microbial activity for bacterial growth, in which partial $\mathrm{NH}_{4}{ }^{+}-\mathrm{N}$ diffused across the CEM from the anolyte to catholyte for its removal. However, increasing the OLR to $870 \mathrm{mgCOD} / \mathrm{L} \cdot \mathrm{d}$ resulted in their values growing to $75.13 \%$ and $71.5 \%$, respectively. Other studies reported the same results (Kõiv et al., 2016; Liu et al., 2016). The possible reason for this is that the amount of $\mathrm{NH}_{4}{ }^{+}-\mathrm{N}$ and $\mathrm{PO}_{4}{ }^{3-}-\mathrm{P}$ used to promote the biomass growth follows a certain organics to nutrients ratio (COD:N:P, in case of biodegradable waste) in the wastewater treatment (Hamza et al., 2019). In this scenario, the growth of OLR may result in increasing the bio-consumption of nutrients. Moreover, it was reported that the amount of nutrients needed for the growth of microorganisms is greater in the high-strength organics wastewater $(\mathrm{COD}>4000 \mathrm{mg} / \mathrm{L})$ when compared to the low-strength organics wastewater such as municipal wastewater (Hamza et al., 2018). The decreased concentration of nutrients in the cathode compartment was ascribed to the recovery of nutrients through struvite precipitation (Ye et al., 2019). However, the enhanced removal of nutrients at the anode chamber may not facilitate the further recovery of $\mathrm{NH}_{4}{ }^{+}-\mathrm{N}$ and $\mathrm{PO}_{4}{ }^{3-}-\mathrm{P}$ in the cathode chamber since this could reduce the amount of nutrients being recovered. Specifically, in this scenario, the average recovery rate of $\mathrm{NH}_{4}{ }^{+}-\mathrm{N}$ declined from $85.11 \%$ to $24.34 \%$ as the OLR increased from 435 to 870 $\mathrm{mgCOD} / \mathrm{L} \cdot \mathrm{d}$. In the study of Chen et al. (2017), they proposed a multi-chamber MFC to recover nutrients from municipal wastewater with the influent COD of $331 \pm 25 \mathrm{mg} / \mathrm{L}$. However, the recovery efficiency of $\mathrm{NH}_{4}{ }^{+}$- $\mathrm{N}$ was lower than $20 \%$ because most ammonium ions were removed through the nitrification-denitrification process. In the present study, the nitrification and denitrification were absent, which improved the recovery of $\mathrm{NH}_{4}{ }^{+}-\mathrm{N}$. On the other hand, although around $83.23 \%$ of $\mathrm{PO}_{4}{ }^{3-}-\mathrm{P}$ could be 
recovered in the first period, this value fell to $24.4 \%$ in the last period. In contrast, Almatouq and Babatunde (2018) found that the growth of influent COD from 500 to $1500 \mathrm{mg} / \mathrm{L}$ caused the enhanced recovery of $\mathrm{PO}_{4}{ }^{3-}-\mathrm{P}$ since higher COD concentrations resulted in the $\mathrm{pH}$ elevation of catholyte and then improve the recovery of $\mathrm{PO}_{4}{ }^{3-}-\mathrm{P}$. The conflict may be attributed to the lower influent COD concentration in the present study, which exerted insignificant impacts on the catholyte $\mathrm{pH}$. Apart from this, the lowest recovery rate of $\mathrm{PO}_{4}{ }^{3-}-\mathrm{P}(24.4 \%)$ was almost the same as the maximum value (27\%) obtained in an air-cathode MFC (Ichihashi \& Hirooka, 2012), which may be attributed to the limitation of single-compartment configuration as discussed above and other factors such as wastewater sources and separator materials.

\section{Conclusion}

Recovering nutrients from sewage was explored at different OLRs in a doublecompartment MFC. The highest voltage generation of $598.9 \mathrm{mV}$ was observed at the OLR of $435 \mathrm{mgCOD} / \mathrm{L} \cdot \mathrm{d}$. The recovery efficiency of $\mathrm{NH}_{4}{ }^{+}-\mathrm{N}$ and $\mathrm{PO}_{4}{ }^{3-}-\mathrm{P}$ also were decreased with increasing the OLR from 435 to $870 \mathrm{mgCOD} / \mathrm{L} \cdot \mathrm{d}$. Conclusively, the dual-chamber MFC could serve as a feasible primary treatment method to recover nutrients and generate electricity from low-strength municipal wastewater. However, the OLR should be optimized if high efficiency in recovering $\mathrm{NH}_{4}{ }^{+}-\mathrm{N}$ and $\mathrm{PO}_{4}{ }^{3-}-\mathrm{P}$, and energy is prioritized.

\section{Acknowledgement}

This research was supported by the Centre for Technology in Water and Wastewater (CTWW), University of Technology, Sydney (UTS, RIA NGO) and Korean Ministry of Environment as a "Global Top Project", Project No. 2016002200005. The authors are 
grateful to the collaborations among CTWW, Joint Research Centre for Protective Infrastructure Technology and Environmental Green Bioprocess and Tianjin Polytechnic University. 


\section{References}

1. Aelterman, P., Versichele, M., Marzorati, M., Boon, N., Verstraete, W. 2008.

Loading rate and external resistance control the electricity generation of microbial fuel cells with different three-dimensional anodes. Bioresource Technology, 99(18), 8895-8902.

2. Almatouq, A., Babatunde, A. 2018. Identifying optimized conditions for concurrent electricity production and phosphorus recovery in a mediator-less dual chamber microbial fuel cell. Applied Energy, 230, 122-134.

3. Angioni, S., Millia, L., Bruni, G., Tealdi, C., Mustarelli, P., Quartarone, E. 2016. Improving the performances of Nafion ${ }^{\mathrm{TM}}$-based membranes for microbial fuel cells with silica-based, organically-functionalized mesostructured fillers. Journal of Power Sources, 334, 120-127.

4. Callegari, A., Cecconet, D., Molognoni, D., Capodaglio, A.G. 2018. Sustainable processing of dairy wastewater: Long-term pilot application of a bio-electrochemical system. Journal of Cleaner Production, 189, 563-569.

5. Chen, X., Sun, D., Zhang, X., Liang, P., Huang, X. 2015. Novel self-driven microbial nutrient recovery cell with simultaneous wastewater purification. Scientific Reports, 5,15744 .

6. Chen, X., Zhou, H., Zuo, K., Zhou, Y., Wang, Q., Sun, D., Gao, Y., Liang, P., Zhang, X., Ren, Z.J. 2017. Self-sustaining advanced wastewater purification and 
simultaneous in situ nutrient recovery in a novel bioelectrochemical system.

Chemical Engineering Journal, 330, 692-697.

7. Colombo, A., Marzorati, S., Lucchini, G., Cristiani, P., Pant, D., Schievano, A. 2017. Assisting cultivation of photosynthetic microorganisms by microbial fuel cells to enhance nutrients recovery from wastewater. Bioresource Technology, 237, 240-248.

8. Curtis, T.P. 2010. Low - Energy Wastewater Treatment: Strategies and Technologies. Environmental Microbiology, Second Edition, 301-318.

9. del Campo, A.G., Lobato, J., Cañizares, P., Rodrigo, M., Morales, F.F. 2013. Shortterm effects of temperature and COD in a microbial fuel cell. Applied Energy, 101, 213-217.

10. Di Lorenzo, M., Scott, K., Curtis, T.P., Head, I.M. 2010. Effect of increasing anode surface area on the performance of a single chamber microbial fuel cell. Chemical Engineering Journal, 156(1), 40-48.

11. Elakkiya, E., Matheswaran, M. 2013. Comparison of anodic metabolisms in bioelectricity production during treatment of dairy wastewater in Microbial Fuel Cell. Bioresource Technology, 136, 407-412.

12. Federation, W.E., Association, A.P.H. 2005. Standard methods for the examination of water and wastewater. American Public Health Association (APHA): Washington, $D C, U S A$. 
13. Franchi, O., Rosenkranz, F., Chamy, R. 2018. Key microbial populations involved in anaerobic degradation of phenol and p-cresol using different inocula. Electronic Journal of Biotechnology, 35, 33-38.

14. Gil, G.-C., Chang, I.-S., Kim, B.H., Kim, M., Jang, J.-K., Park, H.S., Kim, H.J. 2003. Operational parameters affecting the performannce of a mediator-less microbial fuel cell. Biosensors and Bioelectronics, 18(4), 327-334.

15. Gu, Y., Li, Y., Li, X., Luo, P., Wang, H., Robinson, Z.P., Wang, X., Wu, J., Li, F. 2017. The feasibility and challenges of energy self-sufficient wastewater treatment plants. Applied Energy, 204, 1463-1475.

16. Hamza, R.A., Iorhemen, O.T., Zaghloul, M.S., Tay, J.H. 2018. Rapid formation and characterization of aerobic granules in pilot-scale sequential batch reactor for highstrength organic wastewater treatment. Journal of Water Process Engineering, 22, 27-33.

17. Hamza, R.A., Zaghloul, M.S., Iorhemen, O.T., Sheng, Z., Tay, J.H. 2019. Optimization of organics to nutrients (COD: N: P) ratio for aerobic granular sludge treating high-strength organic wastewater. Science of the Total Environment, 650 , 3168-3179.

18. He, Y., Liu, Z., Xing, X.-h., Li, B., Zhang, Y., Shen, R., Zhu, Z., Duan, N. 2015. Carbon nanotubes simultaneously as the anode and microbial carrier for up-flow fixed-bed microbial fuel cell. Biochemical Engineering Journal, 94, 39-44. 
19. He, Z., Minteer, S.D., Angenent, L.T. 2005. Electricity generation from artificial wastewater using an upflow microbial fuel cell. Environmental Science and Technology, 39(14), 5262-5267.

20. Heidrich, E., Curtis, T., Dolfing, J. 2010. Determination of the internal chemical energy of wastewater. Environmental Science \& Technology, 45(2), 827-832.

21. Hiegemann, H., Herzer, D., Nettmann, E., Lübken, M., Schulte, P., Schmelz, K.-G., Gredigk-Hoffmann, S., Wichern, M. 2016. An integrated 45 L pilot microbial fuel cell system at a full-scale wastewater treatment plant. Bioresource Technology, 218, 115-122.

22. Ichihashi, O., Hirooka, K. 2012. Removal and recovery of phosphorus as struvite from swine wastewater using microbial fuel cell. Bioresource Technology, 114, 303307.

23. Jia, H., Yang, G., Wang, J., Ngo, H.H., Guo, W., Zhang, H., Zhang, X. 2016. Performance of a microbial fuel cell-based biosensor for online monitoring in an integrated system combining microbial fuel cell and upflow anaerobic sludge bed reactor. Bioresource Technology, 218, 286-293.

24. Juang, D.-F., Yang, P.-C., Chou, H.-Y., Chiu, L.-J. 2011. Effects of microbial species, organic loading and substrate degradation rate on the power generation capability of microbial fuel cells. Biotechnology Letters, 33(11), 2147. 
25. Kõiv, M., Mahadeo, K., Brient, S., Claveau-Mallet, D., Comeau, Y. 2016.

Treatment of fish farm sludge supernatant by aerated filter beds and steel slag filters-effect of organic loading rate. Ecological Engineering, 94, 190-199.

26. Li, W., Li, L., Qiu, G. 2017. Energy consumption and economic cost of typical wastewater treatment systems in Shenzhen, China. Journal of Cleaner Production, 163, S374-S378.

27. Liu, S., Zhang, G., Zhang, J., Li, X., Li, J. 2016. Performance, carotenoids yield and microbial population dynamics in a photobioreactor system treating acidic wastewater: Effect of hydraulic retention time (HRT) and organic loading rate (OLR). Bioresource Technology, 200, 245-252.

28. Logan, B.E. 2008. Microbial fuel cells. John Wiley \& Sons.

29. Luo, H., Liu, G., Zhang, R., Jin, S. 2009. Phenol degradation in microbial fuel cells. Chemical Engineering Journal, 147(2-3), 259-264.

30. Mardanpour, M.M., Yaghmaei, S., Kalantar, M. 2017. Modeling of microfluidic microbial fuel cells using quantitative bacterial transport parameters. Journal of Power Sources, 342, 1017-1031.

31. Marzorati, S., Schievano, A., Colombo, A., Lucchini, G., Cristiani, P. 2018. Lignocellulosic materials as air-water separators in low-tech microbial fuel cells for nutrients recovery. Journal of Cleaner Production, 170, 1167-1176. 
32. Molognoni, D., Puig, S., Balaguer, M.D., Capodaglio, A.G., Callegari, A., Colprim, J. 2016. Multiparametric control for enhanced biofilm selection in microbial fuel cells. Journal of Chemical Technology \& Biotechnology, 91(6), 1720-1727.

33. Morris, J.M., Jin, S., Crimi, B., Pruden, A. 2009. Microbial fuel cell in enhancing anaerobic biodegradation of diesel. Chemical Engineering Journal, 146(2), 161-167.

34. Puig, S., Coma, M., Desloover, J., Boon, N., Colprim, J.s., Balaguer, M.D. 2012. Autotrophic denitrification in microbial fuel cells treating low ionic strength waters. Environmental Science and Technology, 46(4), 2309-2315.

35. Rossi, R., Yang, W., Zikmund, E., Pant, D., Logan, B.E. 2018. In-situ biofilm removal from air cathodes in microbial fuel cells treating domestic wastewater. Bioresource Technology.

36. Sobieszuk, P., Zamojska-Jaroszewicz, A., Makowski, Ł. 2017. Influence of the operational parameters on bioelectricity generation in continuous microbial fuel cell, experimental and computational fluid dynamics modelling. Journal of Power Sources, 371, 178-187.

37. Tamilarasan, K., Banu, J.R., Jayashree, C., Yogalakshmi, K., Gokulakrishnan, K. 2017. Effect of organic loading rate on electricity generating potential of upflow anaerobic microbial fuel cell treating surgical cotton industry wastewater. Journal of Environmental Chemical Engineering, 5(1), 1021-1026. 
38. Velvizhi, G., Mohan, S.V. 2012. Electrogenic activity and electron losses under increasing organic load of recalcitrant pharmaceutical wastewater. International Journal of Hydrogen Energy, 37(7), 5969-5978.

39. Vicari, F., Albamonte, M., Galia, A., Scialdone, O. 2018. Effect of mode of operation, substrate and final electron acceptor on single-chamber membraneless microbial fuel cell operating with a mixed community. Journal of Electroanalytical Chemistry, 814, 104-110.

40. Wang, J., Zheng, Y., Jia, H., Zhang, H. 2014. Bioelectricity generation in an integrated system combining microbial fuel cell and tubular membrane reactor: Effects of operation parameters performing a microbial fuel cell-based biosensor for tubular membrane bioreactor. Bioresource Technology, 170, 483-490.

41. Wang, X., Feng, Y., Liu, J., Lee, H., Li, C., Li, N., Ren, N. 2010. Sequestration of $\mathrm{CO} 2$ discharged from anode by algal cathode in microbial carbon capture cells (MCCs). Biosensors and Bioelectronics, 25(12), 2639-2643.

42. Wei, L., Yuan, Z., Cui, M., Han, H., Shen, J. 2012. Study on electricity-generation characteristic of two-chambered microbial fuel cell in continuous flow mode.

International Journal of Hydrogen Energy, 37(1), 1067-1073.

43. Xu, J., Luo, P., Lu, B., Wang, H., Wang, X., Wu, J., Yan, J. 2018. Energy-water nexus analysis of wastewater treatment plants (WWTPs) in China based on statistical methodologies. Energy Procedia, 152, 259-264. 
44. Yan, T., Ye, Y., Ma, H., Zhang, Y., Guo, W., Du, B., Wei, Q., Wei, D., Ngo, H.H. 2018. A critical review on membrane hybrid system for nutrient recovery from wastewater. Chemical Engineering Journal.

45. Ye, Y., Ngo, H.H., Guo, W., Liu, Y., Chang, S.W., Nguyen, D.D., Ren, J., Liu, Y., Zhang, X. 2019. Feasibility study on a double chamber microbial fuel cell for nutrient recovery from municipal wastewater. Chemical Engineering Journal, 358, 236-242.

46. Ye, Y., Ngo, H.H., Guo, W., Liu, Y., Li, J., Liu, Y., Zhang, X., Jia, H. 2017. Insight into chemical phosphate recovery from municipal wastewater. Science of the Total Environment, 576, 159-171.

47. Yu, J., Park, Y., Kim, B., Lee, T. 2015. Power densities and microbial communities of brewery wastewater-fed microbial fuel cells according to the initial substrates. Bioprocess and Biosystems Engineering, 38(1), 85-92.

48. Yu, Y., Zou, Z., Wang, S. 2019. Statistical regression modeling for energy consumption in wastewater treatment. Journal of Environmental Sciences, 75, 201208.

49. Zhao, F., Harnisch, F., Schröder, U., Scholz, F., Bogdanoff, P., Herrmann, I. 2006. Challenges and constraints of using oxygen cathodes in microbial fuel cells. Environmental Science \& Technology, 40(17), 5193-5199. 
50. Zhou, M., Yang, J., Wang, H., Jin, T., Xu, D., Gu, T. 2013. Microbial fuel cells and microbial electrolysis cells for the production of bioelectricity and biomaterials.

Environmental Technology, 34(13-14), 1915-1928. 


\section{Figure captions}

Figure 1. COD removal efficiency $v s$ operation time at different OLRs (435-870 $\mathrm{mgCOD} / \mathrm{L} \cdot \mathrm{d}$ ) in the dual-chamber MFC (daily averages \pm standard deviations). Figure 2. Electricity generation vs operation time at different OLRs (435-870 $\mathrm{mgCOD} / \mathrm{L} \cdot \mathrm{d})$ in the dual-chamber MFC (daily averages \pm standard deviations). Figure 3 Maximum voltage and power density $v s$ OLR Figure 4. Variations in the concentrations of (a) $\mathrm{NH}_{4}{ }^{+}-\mathrm{N}$ and (b) $\mathrm{PO}_{4}{ }^{3-}-\mathrm{P}$ in the anode and cathode effluents at different OLRs $(435-870 \mathrm{mgCOD} / \mathrm{L} \cdot \mathrm{d})$ in the dualcompartment MFC (daily averages \pm standard deviations). 


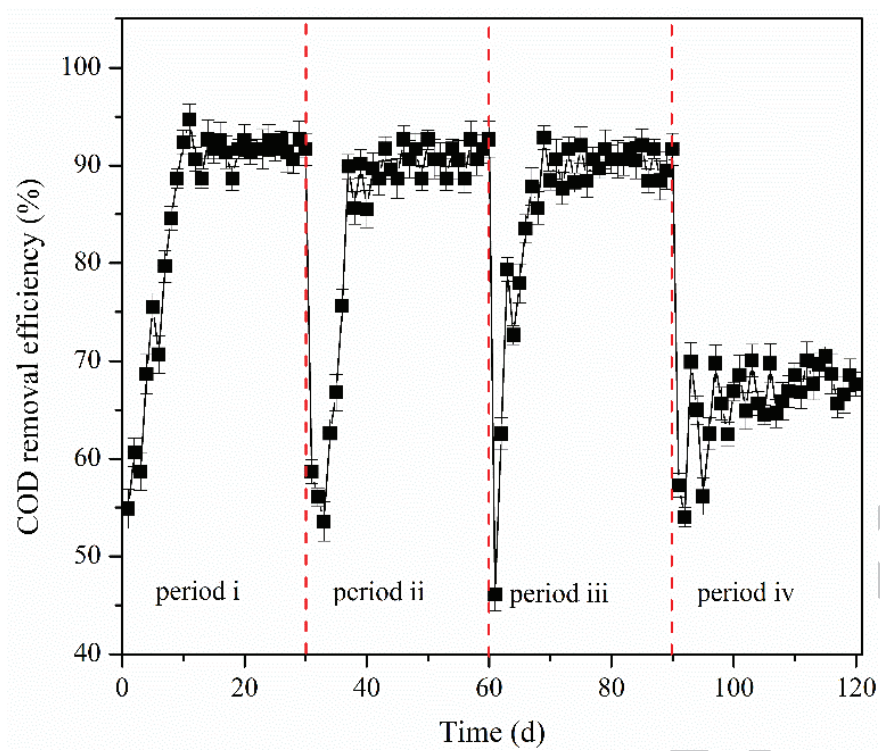

Figure 1. COD removal efficiency $v s$ operation time at different OLRs (435-870 $\operatorname{mgCOD} / \mathrm{L} \cdot \mathrm{d}$ ) in the dual-chamber MFC (daily averages \pm standard deviations). 


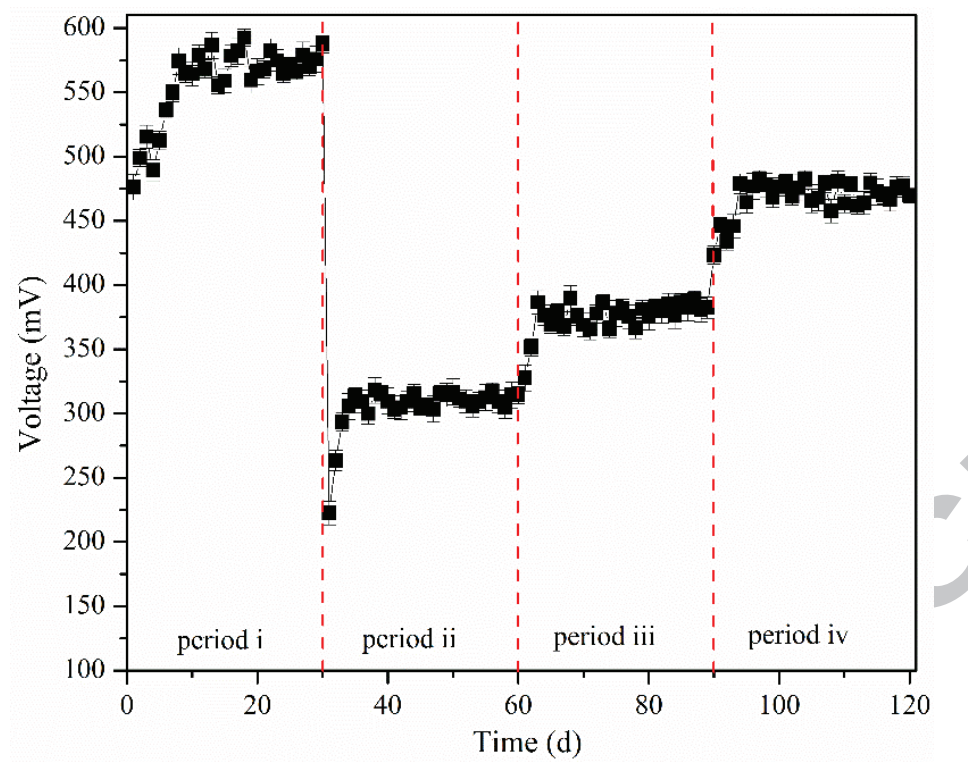

Figure 2. Electricity generation vs operation time at different OLRs (435-870 $\operatorname{mgCOD} / \mathrm{L} \cdot \mathrm{d}$ ) in the dual-chamber MFC (daily averages \pm standard deviations). 


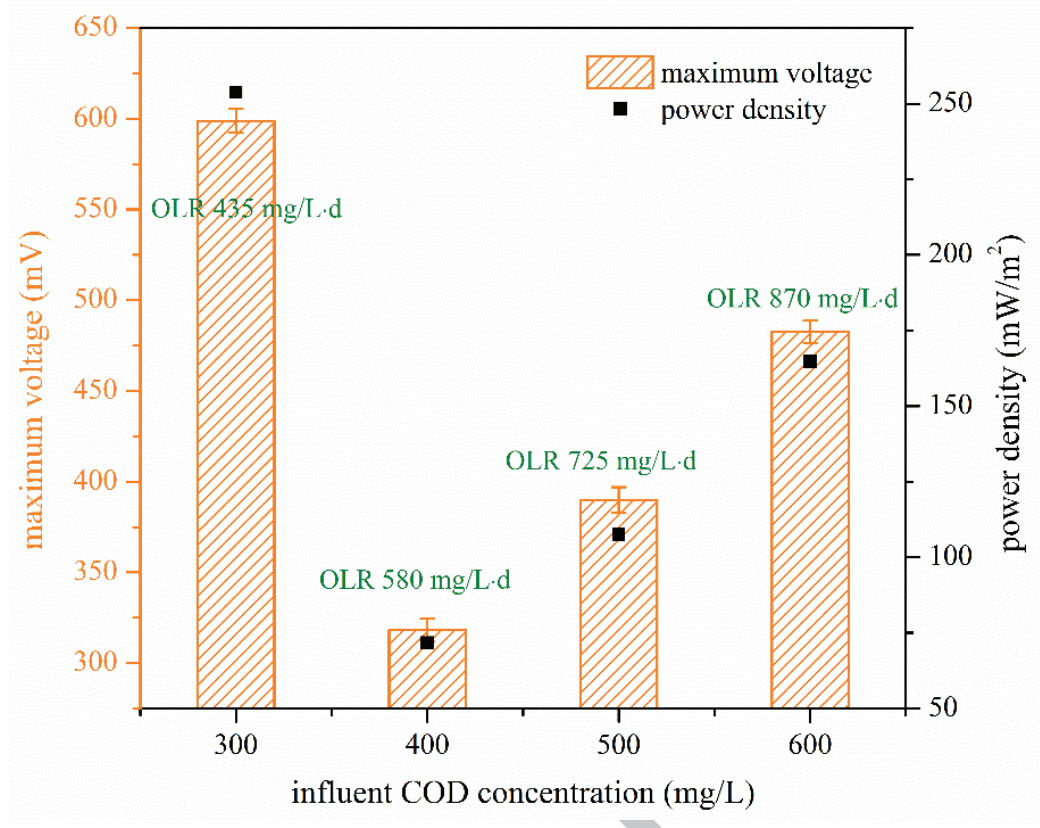

Figure 3 Maximum voltage and power density vs OLR 

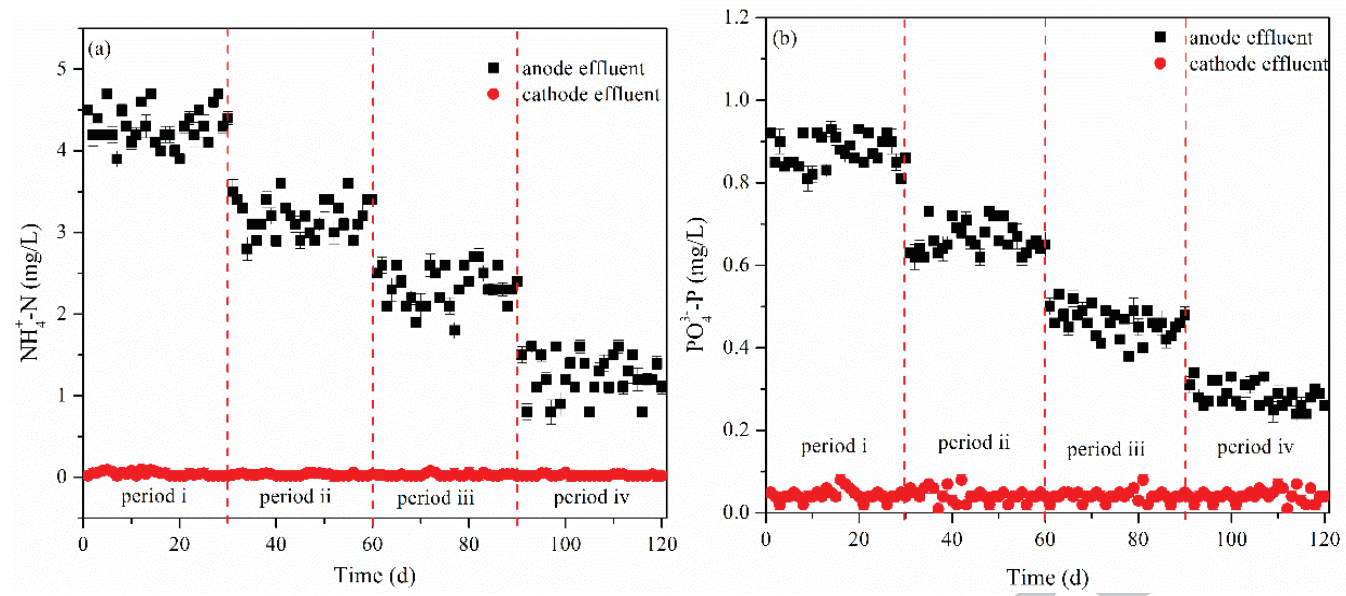

Figure 4. Variations in the concentrations of (a) $\mathrm{NH}_{4}{ }^{+}-\mathrm{N}$ and (b) $\mathrm{PO}_{4}^{3-}-\mathrm{P}$ in the anode and cathode effluents at different OLRs $(435-870 \mathrm{mgCOD} / \mathrm{L} \cdot \mathrm{d})$ in the dualcompartment MFC (daily averages \pm standard deviations). 


\section{Table captions}

Table 1. Operational conditions of the double-chamber MFC 
Table 1. Operational conditions of the double-chamber MFC

\begin{tabular}{ccccc}
\hline Parameters & \multicolumn{4}{c}{ Experimental period } \\
& i & ii & iii & iv \\
\hline Days & $1-30$ & $31-60$ & $61-90$ & $91-120$ \\
Flow rate $(\mathrm{mL} / \mathrm{min})$ & 0.35 & 0.35 & 0.35 & 0.35 \\
HRT $(\mathrm{d})$ & 0.69 & 0.69 & 0.69 & 0.69 \\
Influent COD concentration $(\mathrm{mg} / \mathrm{L})$ & 300 & 400 & 500 & 600 \\
OLR $(\mathrm{mgCOD} / \mathrm{L} \cdot \mathrm{d})$ & 435 & 580 & 725 & 870 \\
\hline
\end{tabular}

\section{Highlights}

Sewage treatment, power output and nutrients recovery were realized via MFCs.

Different OLRs of domestic wastewater affected the electricity generation of MFCs.

High OLR compromised the nutrients recovery from domestic wastewater using MFCs. 